\title{
FP3-1-3：特別企画 3-1-3「関連領域/境界領域からのメッセージ」
}

\section{男性機能領域から}

\section{東邦大学 医学部 泌尿器科学}

石井延久

クエン酸シルデナフィル (バイアグラ TN) の発売により勃起障害 (erectile dysfunction：ED）の治療法はほほ確立した。今後 はバイアグラ無効症例 (NO 生成障害) の病態解明と新しい治療法の開発が課題になる。NO 生成障害は陰茎海綿体の NO 合成醉 素の障嗐から性欲低下 (心因性) まで広い範囲の原因が考えられる。特に動脈硬化は従来から ED の原因として重要な役割を果た すことが報告されてきた。最近、世界各国で行われた ED の疫学調査は榶尿病、高血压、狭心症などの生活習慣病や加令など、動 脈硬化と密接な関連のある病態が ED の危険因子になることを明らかにしている。今後は疫学に関連して ED の予防医学が一つ の方向として注目される。そのためには加令を含めた生活習慣病性 ED の病態を個々に明らかにする必要がある。これは一人でも 多くEDに興味をもつ内科や老人医学領域の専門医を増やす努力が必要と考えている。一方、現時点では器質化した動脈硬化によ るED は陰茎プロステーシス移植手術が唯一の治療になっている。しかし、欧米では動物実験レベルの ED の遗伝子治療に成功し ている。わが国でも遗伝子専門家の ED 治療の参加によるヒトへの応用を期待したい。中枢神経においても性機能に関連する局所 解剖と神経経路の研究は積極的に行われている。特に性欲低下は心理的要因から神経伝達物質の作用まで多くの要因が複雑に関 与しており、全容の解明には解決する問題は多い。しかし、ヨーロッパでは既に中枢性薬物であるアポモルフィン舌下錠が発売さ れ、バイアグラ無効例の範囲も狭くなりつつある。一方、射精障害はまだ臨床的に有効な薬物は開発されていない。最近、選択的 セロトニン再取込み阻害薬（selective serotonin reuptake inhibitor：SSRI）が早漏に有効なことが報告されている。しかし、直接 男性不妊に関与する遅漏や射精欠如には未だ直接有効な根治的薬剤はない。これは射精は勃起に比較するとメカニズムが複雑な ことによる。このように性機能の基礎研究には超えるべきハードルは高い。一方、潜在する ED 患者は多数潜在しており、泌尿器 科医の診療は他臨床領域から難治性 ED が紹介される機会は増加し、更に高度の専門性が要求される。 